\title{
Lidia Amor, El "Roman de Clériadus et Méliadice": la transformación de un paradigma heroico y su vinculación con el poder
}

Maria Colombo Timelli

\section{(2) OpenEdition \\ 1 Journals}

\section{Édition électronique}

URL : http://journals.openedition.org/studifrancesi/6557

DOI : $10.4000 /$ studifrancesi.6557

ISSN : 2421-5856

Éditeur

Rosenberg \& Sellier

Édition imprimée

Date de publication : 1 septembre 2010

Pagination : 343

ISSN : 0039-2944

\section{Référence électronique}

Maria Colombo Timelli, «Lidia Amor, El "Roman de Clériadus et Méliadice": la transformación de un paradigma heroico y su vinculación con el poder », Studi Francesi [En ligne], 161 (LIV | II) | 2010, mis en ligne le 30 novembre 2015, consulté le 11 janvier 2021. URL : http://journals.openedition.org/ studifrancesi/6557 ; DOI : https://doi.org/10.4000/studifrancesi.6557

Ce document a été généré automatiquement le 11 janvier 2021.

\section{cc) (†) $\odot$}

Studi Francesi è distribuita con Licenza Creative Commons Attribuzione - Non commerciale - Non opere derivate 4.0 Internazionale. 


\title{
Lidia Amor, El "Roman de Clériadus et Méliadice": la transformación de un paradigma heroico y su vinculación con el poder
}

\author{
Maria Colombo Timelli
}

\section{RÉFÉRENCE}

LIDIA AMOR, El "Roman de Clériadus et Méliadice": la transformación de un paradigma heroico y su vinculación con el poder, in Derecho y justicia: el poder en la Europa medieval. Droit et justice: le pouvoir dans l'Europe médiévale, coord. par N. GUGLIELMI y A. RUCQUOI, Buenos Aires, CONICET/CNRS, 2008, pp. 215-245.

1 Édité par Gaston Zink en 1984, ce long roman anonyme composé vers la moitié du $\mathrm{XV}^{\mathrm{e}}$ siècle mériterait d'être mieux connu. Lidia Amor, qui lui a consacré sa thèse de doctorat, se concentre dans cet article sur les liens entre la 'carrière' du protagoniste et la gestion du pouvoir monarchique. Clériadus, fils du comte des Astures, écuyer possédant toutes les vertus, est confronté dès le début du roman avec les problèmes politiques du royaume d'Angleterre, dont son père est le 'lieutenant'; épris de la fille du roi, Méliadice, il parviendra à l'épouser et à devenir roi à son tour. Comme Gaston Zink l'avait souligné, les aspects politiques sont au premier plan du récit, farci cependant de motifs romanesques et épiques de tous genres; Lidia Amor met l'accent surtout sur l'habileté de Clériadus à tisser des alliances politiques, et sur la fonction des jeux chevaleresques (joutes, tournois, pas d'armes) et de la guerre dans la structure du roman et dans l'évolution du personnage. 